News from the United States and Canada 


\section{News from the United States and Canada}

\section{APPOINTMENTS AND PROMOTIONS}

In 1968 William $\mathrm{H}$. Hubbard was promoted to assistant professor of history at Loyola College of Montreal and Kenneth W. Rock to the same rank at Colorado State University. During the same year Steven Bela Vardy was promoted to associate professor of history at Duquesne University.

In 1969 Max E. Riedlsperger, a graduate student at the University of Colorado, was appointed lecturer in European history at California State Polytechnic College; and Roy A. Austensen, a graduate student at the University of Illinois at Urbana, assistant professor of history at Illinois State University at Normal. Oleh S. Fedyshyn was promoted to associate professor of political science at Richmond College of the City University of New York. Promoted to professor of history were George Barany, at the University of Denver; Arthur G. Haas, at the University of Tennessee; Bogdan C. Novak, at the University of Toledo; and Gunther E. Rothenberg, at the University of New Mexico.

Seven new appointments were made in 1970 . One of them, that of Richard van Steenkiste, a graduate student at the University of Texas, to assistant professor at Wright State University, was in geography. The rest were in history. Lawrence D. Orton, a graduate student at Indiana University, was appointed instructor at Oakland University. Newly appointed as assistant professor were David C. Danahar, formerly of the University of Massachusetts, at the State University of New York at Oswego; C. Earl Edmondson, previously at the University of North Carolina at Chapel Hill, at Davidson College; Erwin Sicher, formerly at Lynwood Academy, at Andrews University; and Rudolph M. Susel, a graduate student at Indiana University, at Arizona State University. During the same year Alan J. Reinerman left Sacred Heart University to accept a professorship at Appalachian State University.

Also in 1970 Max E. Riedlsperger was promoted to assistant 
professor of history at California State Polytechnic College. Promoted to associate professor were Joseph Held at Rutgers University, Stanley Suval at North Carolina State University at Raleigh, and Douglas A. Unfug at Emory University. Five persons were promoted to professor: Josef Anderle at the University of North Carolina at Chapel Hill, Stanley B. Kimball at Southern Illinois University at Edwardsville, Bela Kiraly at Brooklyn College of the City University of New York, Radomir Luza at Tulane University, and George J. Prpic at John Carroll University. William A. Jenks was made chairman of the history department at Washington and Lee University.

\section{PERSONAL}

Péter Hanák, of the Historical Institute of the Hungarian Academy of Sciences, was visiting professor of history at both Columbia University and Yale University in the spring semester of 1970-1971. At Columbia he taught a colloquium on "Vienna-Budapest-Prague at the Turn of the Twentieth Century." At Yale University he directed a seminar.

Three United States scholars in the Austrian history field have recently served as visiting professors in American and European institutions. At Columbia University Otakar Odložilik, of the University of Pennsylvania, conducted a colloquium in the fall semester of 1969-1970 on East-Central Europe in the late middle ages. Istvan Deak, of Columbia University, taught in 1970 in the summer university at Keszthely, Hungary. Radomir Luza, of Tulane University, was visiting professor of history at the University of Hamburg in 1969-1970.

Several Canadian and United States scholars served on various research and professional committees. In 1970 Peter I. Hidas, of Dawson College, was chairman of the Social Science Council. In August, 1968, Joseph F. Zacek, of the State University of New York at Albany, was one of the two representatives of the American Council of Learned Societies and the Social Science Research Council at the sixth International Congress of Slavists in Prague. He is now a member of the screening committee of the American Historical Association preparing for the participation of United States historians in the seventh International Congress of Slavists in Warsaw in 1973. In June, 1970, Robert A. Kann, of Rutgers 